\title{
DINAMIKA POLITIK DAN HUKUM DALAM MENGGAGAS PARADIGMA HUKUM YANG BERDAULAT
}

\author{
Taufiq Alamsyah \\ Taufiqalamsyah36@gmail.com \\ Gunawan Undang \\ gunawanundang@gmail.com
}

\begin{abstract}
ABSTRAK
Perbincangan politik dan demokrasi seakan tidak pernah selesai. Semenjak founding fathers menorehkan sejarah kemerdekaan bangsa hingga kini, di era Reformasi, politik hukum dan demokratisasi masih tetap menjadi bahan perbincangan. Bahkan, kini, perbincangannya sudah sampai ke masyarakat luas yang dulunya tidak mau tahu dengan persoalan ini. Ini menunjukkan pencerdasan kehidupan politik masyarakat sudah semakin menguat. Karena itulah, kritik terhadap sistem Politik yang otoritarian di Indonesia sepanjang sejarah perjalanan bangsa menemukan momentumnya. Politik adalah sebuah kegiatan yang menyangkut proses pemahaman tentang negara dan masalah kenegaraan serta mempelajari negara beserta tugas-tugasnya. Saat ini politik merupakan sebuah fenomena yang sedang hangat diperbincangkan oleh seluruh lapisan masyarakat. Hampir semua acara ditelevisi sampai acara berbasis komedi pun membahas tentang politik itu sendiri.
\end{abstract}


Dinamika politik pada era modern ini merupakan sebuah persoalan yang kompleks. Banyak perubahan-perubahan yang terjadi yang menyebabkan seseorang memiliki sudut pandang tersendiri atau pemahaman tersendiri yang kuat, sehingga tidak bisa diubah oleh siapapun. Perbedaan ras, agama, serta perbedaan pandang akan politik pun sering tidak bisa berjalan dengan seiringan.

Paham yang dianut negara Indonesia adalah sebuah paham demokrasi. Paham demokrasi berlaku pada semua bidang yaitu bidang sosial budaya, bidang agama, bidang ekonomi termasuk bidang politik. Politik demokrasi adalah sebuah politik dimana didalamnya memberikan perlakuan yang sama serta sangat menghargai sebuah perbedaan baik pada kaum mayoritas maupun kaum minoritas.

Kata kunci : Hukum, Politik, Perkembangan, Indonesia.

\section{PENDAHULUAN}

Indonesia merupakan negara hukum (Rechtstaat) tidak berdasar atas kekuasaan belaka (Machstaat) dimana didalamnya pasti mengerucut pada lembaga peradilan. Pada satu sisi, hukum diharapkan mampu menjadi kekuatan terciptanya era baru Indonesia, menjadi wacana terwujudnya "Civil Society" (masyarakat madani). Pada sisi lain, hukum seakan-akan telah kehilangan supremasinya.

Namun, sebenarnya tidak hanya hukum yang merupakan faktor pendorong, karena ia merupakan dwi tunggal dengan demokrasi. Sejak lahirnya negara Republik Indonesia dengan UUD 1945-nya, demokrasi Indonesia dalam perkembangannya telah melewati demokrasi konstitusional, demokrasi liberal, demokrasi terpimpin, da demokrasi Pancasila. Tetapi, belum pernah mampu menemukan bentuk/ sistemnya yang sejati. 
Demokrasi dalam sistem kenegaraan Indonesia hanya berfungsi sebagai kamuflase kepentingan penguasa dan sekaligus meligitimasi kebijakan publik penguasa. Dalam banyak hal, penguasa mengklaim menerapkan prinsip dan nilai demokrasi. Tetapi, justru melakukan tindakan kontradiktif, yang mempresentasikan berbagai penyelewengan terhadap prinsip-prinsip dan nilai-nilai demokrasi itu sendiri. Dalam keadaan demikian, supremasi hukum sulit untuk diwujudkan. Pada akhirnya, demokrasi susah diwujudkan karena jaminan kepastian hukumnya lemah.

Negara yang didasari atas hukum ditandai dengan semua perbuatan atau tindakan seseorang, kelompok, maupun individu, serta rakyat maupun pemerintah berdasarkan ketentuan dan perundang-undangan yang berlaku. Negara yang merupakan negara hukum harus didasari hukum yang baik dan adil tanpa membedabedakan. Hukum yang baik harus bersifat demokratis yaitu berdasarkan kepada kehendak rakyat. Dengan ciri lain yaitu mengandung perintah dan larangan, menuntut kepatuhan dengan adanya sanksi, maka hukum yang berjalan akan menciptakan ketertiban dan keadilan di masyarakat.

Tokoh pencipta negara hukum Immanuel Kant dan Fichte, mendefinisikan sebagai berikut : negara hukum adalah negara yang tugas pokoknya hanyalah membentuk hukum, melaksanakan hukum, serta mempertahankan pelaksanaan hukum dalam rangka menciptakan serta mempertahankan ketertiban, dan keamanan negara, agar para warga negaranya dapat dengan tenang melaksanakan tugas dan kewajibannya.

Berbicara tentang hukum pasti sedikit banyaknya terarah pada hal Politik. Dimana politik itu adalah proses pembentukan dan pembagian kekauasaan dalam unsur masyarakat untuk pembuatan keputusan dalam negara. Hukum bekerja dalam situasi politik tertentu yang dimaksud sebagai perwujudan nilai-nilai yang berkembang dengan nilai-nilai keadilan. Politik dan hukum seiring berubahnya zaman pasti mengalami sebuah perubahan. Memahami sebuah perubahan harus 
dilihat dari sebuah akar filsafah pemikiran yang dominan. Perdebatan mengenai hukum dan politik memiliki akar sejarah yang panjang. Bagi penganut aliran positivisme seperti John Austin, hukum adalah tidak lain dari produk politik atau kekuasaan.

Transfromasi identik dengan sebuah perubahan yaitu sebuah proses perubahan secara berangsur menuju sistem yang dianggap lebih baik dan mendukung. Perubahan ini dilandasi oleh situasi dan kondisi yang menuntut sebuah sistem untuk berubah dengan melakukan suatu perubahan dengan visi dan misi yang jelas.

Sebuah transformasi di politik dalam hukum banyak mengalami perbedaan pandangan. Ketimpangan-ketimpangan itu terjadi bisa disebabkan oleh proses penegakan hukum yang salah. Secara pendapat konsepsionil, Hukum tidak hanya terdiri dari "law enforcement" (yang dewasa ini tidak begitu gencar terdengar dalam pembicaraan sehari-hari; berbeda dengan beberapa yang lampau, di mana hampir setiap hari hal itu di dengung-dengungkan); penegakan hukum juga mencakup pencipta kedamaian. ${ }^{1}$

Politik dahulu merupakan kebijakan dimana orang tidak ada mencari kedudukan,ataupun mencari uang dalam politik tersebut, tetapi bagaimana cara mengamalkan potensi yang ada pada diri nya untuk kepentingan masyarakat dan negara. Politik zaman dahulu tidak haus akan kekuasaan, bahkan materil. Politik zaman dahulu bersifat ingin membangun negara Indonesia meskupin terdapat pula masalah-masalah yang terjadi.

Politik masa Prakolonial Indonesia dimana sebelum kekuatan Eropa Barat mampu menguasai daratan dan perairan Asia. Di zaman ini menunjukkan bahwa Nusantara berisikan berbagai entitas politik sejak awal sejarah. Berevolusi dari pusat

\footnotetext{
${ }^{1}$ Soerjono Soekanto, dan Mustafa Abullah, Sosiologi Hukum dalam Masyarakat, Cetakan
} ketiga (Jakarta: Rajawali, 1987), h. 30. 
politik di sekitar perorangan di mana ke pemimpinannya diwujudkan dalam diri seseorang yang mempunyai keterampilan tertentu di dukung oleh tentara dan rakyat.

Politik masa Penjajahan Indonesia di zaman ini kedatangan bangsa Eropa yang tertarik menjadikan perdagangan rempah-rempah adalah sebuah titik utama dalam sejarah. Portugis dan Belanda berhasil menjadi pemegang kekuatan ekonomi dan politik yang berpengaruh dan mampu mendominasi negara ini menciptakan kerangka-kerangka politik dan batas-batas baru.

Politik pada masa Orde Lama pemerintahan Soekarno yaitu Tokoh Pahlawan Nasional yang gemar dengan buku-buku filosofis, politik. Pada masa ini banyak sekali yang harus dibenahi dan diatur yang menyebabkan kondisi politik masa itu tidak tertentu. Kelebihan politik pada masa ini yaitu dikeluarkannya TRIKORA, Konferensi Milano, berhasilnya diadakan Pemilu 1955, Pembubaran Konstituante untuk digunakannya kembali UUD 1945.

Politik pada masa Orde Baru pemerintahan Soeharto Pada masa pemerintahan Soeharto Indonesia mengalami krisis ekonomi hingga politik yang lumayan parah. Krisis politik yang terjadi pada tahun 1998 merupakan puncak dari berbagai kebijakan politik pemerintahan Orde Baru. Pemerintah selalu beralasan dengan demokrasi Pancasila namun demokrasi yang dilaksanakan pemerintahan Orde Baru bukan demokrasi yang semestinya, melainkan demokrasi rekayasa yang berarti dari, oleh, dan untuk rakyat, melainkan demokrasi yang berarti dari, oleh, dan untuk penguasa hingga akhirnya munculah gerakan-gerakan mahasiswa dan masyarakat yang meminta presiden yang sedang berkuasa di kala itu untuk turun menyerahkan jabatannya.

Sejak berakhirnya Orde Baru yang dipimpin presiden Soeharto dan mulainya periode Reformasi. Reformasi lahir ketika negara ini mengalami krisis yang melanda berbagai aspek mulai dari kehidupan ekonomi, politik, hukum dan bahkan krisis kebutuhan pokok. Setiap pemilu di Indonesia dianggap bebas dan adil. Namun, 
Indonesia belum bebas dari korupsi, kolusi dan nepotisme maupun 'politik uang' di mana orang bisa membeli kekuasaan atau posisi politik. Masa Reformasi setelah Habibie menjadi presiden, kondisi politik kian berubah. Proses dan praktik demokrasi di Indonesia mulai membaik. Presiden mulai dipilih berdasarkan pemilu dalam skala 5 tahun sekali, dan semua masyarakat berhak untuk memilih pemimpinnya.

Politik merupakan suatu fenomena atau kejadian yang sangat hits pada masa era ini. Politik pada zaman sekarang banyak sekali mengalami kesalahpahaman padahal ada banyak nilai-nilai yang bisa dikaji dan diterapkan pada zaman sekarang, terutama bagaimana relasi antara NKRI dengan Pancasila dan Undang-Undang Dasar 1945. Perubahan politik mulai ini terjadi ketika masa orde baru dimana orang sudah melihat kedudukan itu dapat menghasilkan uang, sehingga saat ini diukur dengan uang bukan dengan pengabdian yang tulus kepada masyarakat, bangsa dan negara.

Dunia perpolitikan pada era modern di Indonesia ini sedang sangat panaspanasnya. Pada saat ini, masalah politik yang dihadapi negara kita Indonesia ini yaitu maraknya partai-partai politik yang memilih selebritis tanah air untuk menjadikan anggota partainya. Dipilihnya selebritas tanah air dengan maksud mengambil kepopuleran padahal kinerja dari para selebritis tersebut tidak menjamin. Karena yang sebenarnya dibutuhkan dalam dunia kepolitikan adalah kinerja yang optimal yang menjadikan politik Indonesia menjadi lebih baik daripada sebelumnya. Tetapi yg terjadi saat ini politik sudah dijadikan bahan untuk mencari kedudukan,mencari harga diri maupun mencari uang (Materialisme).

Manusia-manusia di zaman milenial ini mempunyai sifat individualisme, egoisme yang hanya memikirkan apa yang ada diperutnya bukan untuk perut rakyatnya. Jarang individu-individu menyadari bahwa konflik di negara kita di latari oleh pertarungan ideologis, perbedaan kepentingan politk antar elit, serta rivalitas yang hanya mementingkan dirinya semata. 
Masalah yang dihadapi oleh Indonesia saat ini yaitu hilangnya atau memudarnya nilai Pancasila dalam lingkungan masyarakat dan kepolitikan. Memudarnya nilai Pancasila tidak lagi dijunjung tinggi serta tidak dihiraukan lagi oleh sebagian rakyar Indonesia. Serta berkurangnya apa arti demokrasi sendiri dalam kehidupan sehari-hari.

Uang korupsi yang semakin menumpuk tanpa ada rasa sadar yang enggan dipikirkan kemana rezeki halal itu didapat, pelecehan seksual semakin meluas bahkan diperdagangkan. Hak moral dan hak-hak politik yang terjadi makin terasa kompleks tanpa takut akan ada hukuman yang dijerat bagi pelanggarnya.

Politik pada zaman ini juga melihat sebagai segala kegiatan mencari dan mempertahankan kekuasaan. Pandangan ini memang cukup luas, namun dilihat dari sebuah konsepnya yang membuat kata politik saat ini ditakutkan seperti hukum rimba "siapa yang kuat dialah yang menang". Kecenderungan perpolitikan Indonesia yang memandang kekuasaan adalah "makanan empuk" yang harus didapatkan dengan bagaimanapun caranya. Kekuasaan sejatinya adalah amanah yang harus dipertanggungjawabkan nantinya bukan bahan perebutan bak makanan yang lezat.

Paham akan Pancasila dan demokrasi sendiri menjadi dasar negara ini. Kekayaan dan keragaman adalah asset besar yang dimilik oleh bangsa Indonesia. Dalam dunia politik inilah kita dapat berkontribusi mengeluarkan aspirasi-aspirasi apa yang ingin kita sampaikan, kita telaah, kita pelajari tentang permasalahanpermasalahan yang terjadi di negara kita ini.

\section{Pemberdayaan Hukum dan Demokrasi Indonesia}

Dalam konteks ini, dua hal pokok yang perlu dikemukakan : (1) pembentukan hukum yang obyektif, tidak direkayasa oleh badan atau lembaga yang berwenang membentuknya; dan (2) kesadaran, baik kesadaran para penguasa maupun kesadaran masyarakat untuk mematuhi hukum dan prinsip-prinsip demokrasi. 
Sehubungan dengan dua hal pokok ini, dapat disimpulkan bahwa bangsa Indonesia hendak melakukan reformasi politik, hukum dan demokrasi. Karena reformasi adalah suatu keharusan dalam membangun Indonesia Baru.

Ada tiga hal yang patut direnungkan dalam usaha memberdayakan hukum dan demokrasi Indonesia, terutama yang terkait dengan peranan MPR/ DPR :

a. pemilihan dan pengangkatan keanggotaan DPR/MPR karena, ini menenttukan kualitas kenggotaan DPR/MPR.

b. Mekanisme kinerja internal DPR, yang sampai saat ini masih tetap merupakan kendala bagi DPR untuk mewujudkan wewenang dan tugas serta fungsi DPR secara optimal.

c. Lembaga Kepresidenan. Dalam hal ini yang penting adalah bahwa Presiden, baik dalam kedudukannya sebagai pemegang kekuakaan membentuk UU dengan persetujuan DPR, sebagai Kepala Pemerintahan, dan sebagai Kepala Negara dan pemimpin seluruh rakyat, maka Pressiden harus menjadi Pemimpin Negara sejati yang mengayomi rakyat seluruhnya. Kepala Negara harus mampu berdiri di atas semua golongan dan aliran serta mempersatukan bangsa dan negara.

Era politik di masa pemerintahan Presiden Jokowi sesungguhnya juga membawa relasi politik yang cukup positif sekaligus problematik. Banyak pro dan kontra yang terjadi pada politik masa modern ini. Sebagai masyarakat di era globalisasi kita harus selalu open mind atau terbuka untuk pendapat lain yang masuk. Tidak mungkin semua orang bisa satu pikiran dengan kita atau satu pendapat. Opini publik terbentuk karena suatu hal yang dipandang seseorang secara bersamaan dan menghasilkan suatu opini yang belum tentu benar atau belum tentu salah, Berfikir kritis serta melihat apa yang menjadi sumber-sumber perubahan yang ada negara kita merupakan hal yang tepat untuk saat ini. 


\section{PENUTUP}

Dinamika politik dalam hukum yang berkembang di Indonesia terbilang sangat kompleks. Banyak perjalanan-perjalanan suka duka yang telah dilalui oleh perpolitikan di Indonesia ini. Banyak pro dan kontra yang menyulut amarah-amarah tentang permasalahan akan negara tercinta kita ini.

Permasalahan terberat pada negeri kita ini terjadi pada masa pemerintahan Soeharto karena politik pada masa itu sedang tidak stabil. Banyaknya pemberontakan-pemberontakan yang dilakukan oleh anak muda untuk menuntut hakhaknya hingga presiden pada saat itu turun dari masa jabatannya.

Banyak para elit politik yang salah menggunakan kekuasaan di dalam politik itu sendiri. Politik Indonesia membutuhkan manusia-manusia terampil agar kerja yang dihasilkan secara optimal, efektif, dan efisien untuk merubah negara kita.

Proses perpolitikan yang panjang bukan berarti menjadikan politik Indonesia kedalam politik yang berpangku pada rasa demokrasi. Perpolitikan zaman milenial ini hanya memikirkan dirinya sendiri tanpa memikirkan bagaimana orang lain. Kurangnya kesadaran akan membangun rasa demokrasi dalam politik merupakan masalah yang belum bisa dihilangkan.

Sebagai kaum muda kita harus merubah hal-hal demikian ini, kita harus mulai berfikir kritis untuk kemajuan bangsa dan harus menemukan jalan keluar serta solusi, tidak hanya sekedar berkomentar, mengkritik, bahkan menghujat. Ambilah gerakan yang kalian bisa untuk merubahnya. Kita tidak boleh bersikap acuh tak acuh terhadap persoalan yang ada. Dengan masalah ini kita dapat menjadikannya sebagai motivasi untuk persatuan bangsa ini. 


\section{DAFTAR PUSTAKA}

Sintaningrum, Heru Nurasa dan Yogi S. 2011. Transformasi Administrasi Negara Perspektif Politik dan Kebijakan Publik. Jakarta: Falsafa.

Soehino, SH. Hukum Tata Negara - Negara Kesatuan Republik Indonesia Berdasarkan Undang-Undang Dasar 1945 adalah Negara Hukum, Yogyakarta: Liberty, 1985.

M. AS. Hikam, Mulyana W. Kusumah dkk, Wacana Politik Hukum \& Demokrasi Indonesia, Yogyakarta, Pustaka Pelajar, 1999.

https://www.academia.edu/16459844/Kondisi_Politik_Ekonomi_dll_Indonesia_pada

_Masa_Pemerintahan_Soekarno/diakses pada 25 November 2019

Setiyono,Budi.(2010). Korupsi,Transisi Demokrasi \& Peran Organisasi Civil Society(CSO). Jurnal Ilmu Politik, Vol.1 No.1.

Lathif, Ah Azharuddin.(2011). Akomodasi Pemerintahan RI Era Reformasi Dalam Pelaksanaan Syariat Islam Di Aceh. Jurnal Ilmu Politik, Vol.2, 654,876.

https://nasional.kompas.com/ diakses pada 25 November 2019

https://ctzonedehasenbkl.com/ diakses pada 24 November 2019 
